\title{
APPLICATION OF SYSTEMIC VISION IN THE EDUCATIONAL PROCESS
}

\section{PROBLEMS \\ OF MANAGEMENT \\ IN THE $21^{\text {st }}$ CENTURY Volume 5, 2012}

\author{
Nilton Cesar Lima \\ Federal University of Alagoas, Brazil \\ E-mail: cesarlim@yahoo.com
}

Antonio Sergio Torres Penedo

Federal University of Rio Grande do Norte, Brazil

E-mail: astpenedo@yahoo.com.br

\author{
Marcio Mattos Borges de Oliveira, Sonia Valle Walter Borges de Oliveira \\ University of Sao Paulo, Brazil \\ E-mail: mmattos@usp.br, soniawv@usp.br \\ Jamerson Viegas Queiroz \\ Federal University of Rio Grande do Norte, Brazil \\ E-mail: viegasqueiroz@gmail.com
}

\begin{abstract}
As the sophistication of technology is increasing, also increased the demand for quality in education. The expectation for quality has promoted broad range of products and systems, including in education. These factors include the increased diversity in the student body, which requires greater emphasis that allows a simple and dynamic model in the provision of education. For this reason, a formalized methodology known as systems theory is often applied in the industry as a management instrument, or in other words, known as systems management. The management of educational systems would be adherent to ally in reducing failure rates and quality improvement. This is possible in complex learning systems scale. Accordingly, this article aims to discuss some implications of trying to use the systems management as modern teaching methodology.
\end{abstract}

Key words: educational learning, systemic vision, educational technology.

\section{Introduction}

Educational systems, understood as practical systems, usually represent a sum of some components for its functionality. The individual behavior on school management decisions represents a part of the systemic component, and this must act in a manner between the parties or other integrative functional areas in the school. The modern system of learning has many systemic components and requires monitoring and adjustment of flexibly among organizational decisions so that the actions can be integrated. For example, the integrated software system, which reveals a need for employing systematic processes to help the management. In the field of education the systemic approach is relevant, given the increasing complexity of modern systems of learning. There are several emerging trends in education that serve to make useful systems with regard to complexity. The first trend that stands out is the increased use of sophisticated virtual installations, configuring a physical learning environment (face to face) to the virtual, 
PROBLEMS

OF MANAGEMENT

IN THE $21^{\text {st }}$ CENTURY

Volume 5, 2012

62

the so-called distance learning, which increases the number of entries in the system. In other words, the input of resources to the system not only includes the physical environment class, annotations of classes, lectures, presentations etc. (scenario traditional education), currently the videos, the internet which provides with the use of the virtual environment of the classroom, on-line solutions questions, learning exercises and interactivity, forums, chats, groups of studies etc. comes to reveal a new paradigm in education, and this fall in an environment where the management adopts more complex systems for the management and decision-making processes.

It is assumed that people using the technology, and the situations in which it is used, are more or less homogeneous (Oliver, 2005). But the author discusses this in relation to models of technology diffusion, and we know that technology is the cause of change to cause improvements in learning outcomes and efficiency of education.

Currently there are many learning paths and used the challenge to organizational systems. Integrated learning systems the grille disciplining is designed to suit an audience whose temporal aspect was the problems in educational development. These integrated systems related to the use of sophisticated software require teaching professionals from different areas and with ease of transmission of knowledge in the virtual environment and use of computational tools and high-tech software. In this context is the object of study, systemic approach of learning in education, subject still little discussed by scholars. When it comes to breaking the paradigm between different areas of teaching, whose instrumental knowledge transmission represents the divisor of what was traditional for what it conceives as modern education virtual environment.

Meyer-Adams (2011) argues for the need of understanding from a systems perspective on the use of educational technology. For the author, the academic study with the use of educational technology should be comprehensive in social scientific lines.

If educational technology in learning is able to extend the power and morality (Friesen, 2008; Selwyn, 2010). In this context the ability to intervene, to change and alter the circumstances that affect a person becomes a key issue and can be perceived in its systemic understanding (Feenburg, 2001).

Therefore, an in-depth study on this subject can contribute with important tools for decision-making on school management will offer quality education student needs that United many times is committed to education by the time factor or willingness to learn, which in turn fails to create lasting competitive advantages, saturating the region, and therefore downloading problems for the future. The educational environment is at the Centre of a multifaceted transformation: social, political, economic, cultural and epistemological, which affects individuals, groups and social institutions, crossed by dilemmas and perspectives, fittings and dislocation, promises and deficits in General, amazing, terrifying or exciting, and that considerable changes have been promoting in habits, customs and understanding of reality. Given these transformations a challenge imposes itself to the school, to form autonomous intellectual subjects, ethics, cultural and politically able to enter with dignity in this society. To this end, it is necessary to seek a methodological path to think about the school, incorporating macro-and micro-elements that make up the complexity of its reality; a reality that is part of a broad movement, but that at the same time is from a local and particular movement. As an example, pedagogical alternatives geared to the virtual teaching, taking this context, reflections and contributions to public policy tools in vigorous education.

For Meyer-Adams (2011) these alternatives may offer explanations of how management practices coupled with the use of technologies influence the diffusion of learning and how actions can be observed systemic practice social and moral sensibility.

Considering that the educational environment in society and undergoes various transformations promoting great influence on local development and the provision of experiences to scholars in understanding their functionality can offer great contribution to society, through 
the concept of systemic vision. In other words, to understand the method of learning in education from the design of the systemic vision, whose environments as part of the education are actors that contribute to its functionality. However, the central problem of research that guides this study is literally formulated as follows: How is presented the educational learning from the design of the systemic vision? To answer this question, this study aims to: analyze the functionality of the education in systemic levels noting their influences on construction of learning development in education.

\section{Systemic Teaching}

According to Chiavenato (2003, p. 54), "the scientific management initiated by Taylor and his followers, is the first administrative theory. The concern to create a science of administration began with the concrete and immediate experience of work of workers and with the emphasis on tasks". Yet for the author, it was noted that Frederick Winslow Taylor led the scientific management movement with the theoretical versed on efficiency of manufacturing processes, whose principles and techniques created by this movement sought to increase production efficiency through the rationalization of work to prevent waste and promote the prosperity of bosses and employees. Namely, his contribution to management theory has shown that economic prosperity is only possible with maximizing the productivity of workers.

This efficiency was only possible with the redesign of work and workers' attitudes change. The redesign was necessary because there were no methods, because without workers methods were the tasks according to hunches or intuition, and it is not possible to assess performance. So, Taylor turned to the rationalization of the work of workers, extending in the second sentence of the definition of the management principles applicable to all situations, taking as a starting point the principles of technology of his time to manual labor, which sought to impose on manual operations the same principles that the designers applied to operations of the machines in the 19th century.

He identified the work to be done individually, assigning the right way to perform each operation, trying to find a sequel that could be faster and in shorter time and movements. Known as Cartesian method, and that today seems to be common, but it was the first time that gave attention to manual labor, is not only considered as simply a natural fact, serving to establish the theory of administration. Another approach to pay for training of management theory was the Fordism; the rationalization of production provided the Assembly line that allows the serial production. This theory, mass production, was brought by Henry Ford. Mass production represented, so manufacture of non-differentiated products in large quantities from the design of standardized parts and specialized worker.

According to Chiavenato (2003, p. 65), in the production in series or in mass, the product is standardized, as well as the machinery, the material, the workmanship and the design of the product, which provides the minimum cost. Hence, the production in large quantities, which previous condition is the ability of mass consumption. The acceptance of theories of scientific management and administration - scientific administration of the assembly line is responsible for the remarkable expansion of industrial activity around the world. The vision of Henri Fayol, another precious source for management theory whose studies turned on to the tasks of the Administration, now known for areas such as: General Administration, production, operation, commercial, human resources and marketing. According to Chiavenato (2003, p. 81), "the concept of management Fayol was in the Act of administering that involved: predict, control, coordinate and control".

Therefore, pioneered in the definition of the Administration as the process of planning, organizing, directing and controlling, and should this be seen as a separate function from the other functions (areas) of the company. His theory brought the idea of the management system, 
PROBLEMS

OF MANAGEMENT

IN THE $21^{\text {st }}$ CENTURY

Volume 5, 2012

64

and should be divided into three parts: 1-the Administration in its concept seen above, is a separate function from the other functions (the areas) such as: technical, commercial, financial, security and accounting; 2-as a concept, the administration represents the process of planning, organization, command, coordination and control. The on command and coordination approach is seen by leadership, being assigned on execution function; 3-the management system can be taught and learned.

Another great theoretician of administration was Max Weber, who studied formal organizations, being the author of the concept of "ideal type" of bureaucracy. He admitted that in organizing the paperwork indicated the rationality of the laws. Are the laws that govern the behavior of people. The "ideal type" for it, is not a prescriptive model, but a descriptive abstraction. All modern organizations, from small businesses to large corporations should be governed bureaucratically for being the most rational way of exerting domination. The bureaucracy in bureaucratic organization seeks a formal character who obeys the rules imposed on its accuracy means much more than discipline and confidence, as well as the achievement of efficiency. There have been studies of the theory of administration who sought other approaches like behavioral and systemic, the first centered on people as the most important part of the Organization, and others like: interests, feelings, behavior, social system, individuality, quality, well-being at work, group dynamics, leadership and managerial role. The second is a theory that reorients the thinking and worldview. What prior to the Organization of work through specialization of labor worker, in time and motion studies and on the Division of labor, in which represented the focus of study in classical studies, now the Administration will give emphasis on analysis of bureaucratic organization. Wage incentives and even in awards given by the productions obtained, representing the way of managing an organization, i.e. before the only source that motivated workers were paid salaries as a reward on what produced or performed within expectations. This new theory, as is also discussed further in the next units, identifies the efficiency in its bureaucratic point of view to the achievement of efficiency.

However, before the theory of streamlining the work of the workman was not enough if the Manager or higher grown the same optics of simple work, in other words, it was necessary to motivate and involve higher hierarchical levels, scientific administration engineers began to worry about the management principles related to the behavior of top management integrated into productive activity. This represented a critique of scientific management, called by some as the theory of the machine, the Super-specialization that worker robotize peoples ', where the worker was seen in a straightforward manner. Therefore a more complete approach, and is where he was employed the formal and informal organization in the field of application, but is important to say that the set of all these theories were instrumental for the characterization of time and motion and administrative theory on the Division of labor, in which represented the focus of study in classical studies, now the Administration will give emphasis on analysis of bureaucratic organization. Wage incentives and even in awards given by the productions obtained, representing the way of managing an organization, i.e. before the only source that motivated workers were paid salaries as a reward on what produced or performed within expectations.

\section{The Viable System Model (VSM)}

A viable system is a system able to exist independently. Although an independent existence, that allows a certain autonomy, an organization does not live in a vacuum, that is, does not exist without an external environment that influences. Normally, when referring to a company/organization is viable, associates itself to economic viability. From this concern with the economic dimension, is the idea that most problems are economic in nature, but according to Beer (1967), this idea is wrong. Solvency and profitability are prerequisites of the activity; 
Nilton Cesar LIMA, Antonio Sergio Torres PENEDO, Marcio Mattos Borges de OLIVEIRA, Sonia Valle Walter Borges de OLIVEIRA, Jamerson Viegas QUEIROZ. Application of Systemic Vision in the Educational Process

however, these aspects are not the identity of the company, while serving to support the existence of same.

Petit (1967) and Mattar (2003) present a systemic conception of the company, according to Quadro1. About this approach they claim that the technical level has borders that do not isolate completely the environment but that have a high degree of closure. The organizational level features lower closing level: therefore it is more susceptible to infiltration of foreign elements. Institutional level already have very permeable borders, suffering, therefore, strong influence of factors difficult to control and predict.

\section{Table 1. The technical, organizational and institutional levels of the administra- tion system.}

\begin{tabular}{|c|c|c|c|c|c|}
\hline $\begin{array}{c}\text { Management } \\
\text { Level }\end{array}$ & Task & Approach & Used Technique & Time's horizon & $\begin{array}{c}\text { Strategies in } \\
\text { decision }\end{array}$ \\
\hline Technical & $\begin{array}{c}\text { Technical ratio- } \\
\text { nality }\end{array}$ & Technique & $\begin{array}{c}\text { Scientific admin- } \\
\text { istration }\end{array}$ & Short period & Computing \\
\hline Organizational & Coordination & Politics & Mediation & Short period & Compromise \\
\hline Institutional & $\begin{array}{c}\text { Consideration } \\
\text { of uncertainties, } \\
\text { relationship with } \\
\text { the environment }\end{array}$ & $\begin{array}{c}\text { Conceptual and } \\
\text { philosophical }\end{array}$ & $\begin{array}{c}\text { Timely supervi- } \\
\text { sion and nego- } \\
\text { tiation with the } \\
\text { environment }\end{array}$ & Long period & Judgment based \\
\hline
\end{tabular}

Source: Based on Mattar (2003).

Schwaninger (1993, p. 63) and Mattar (2003: 02) present the schema of a corporate structure based on the model of viable system from Beer, as reproduction in Figure 1.

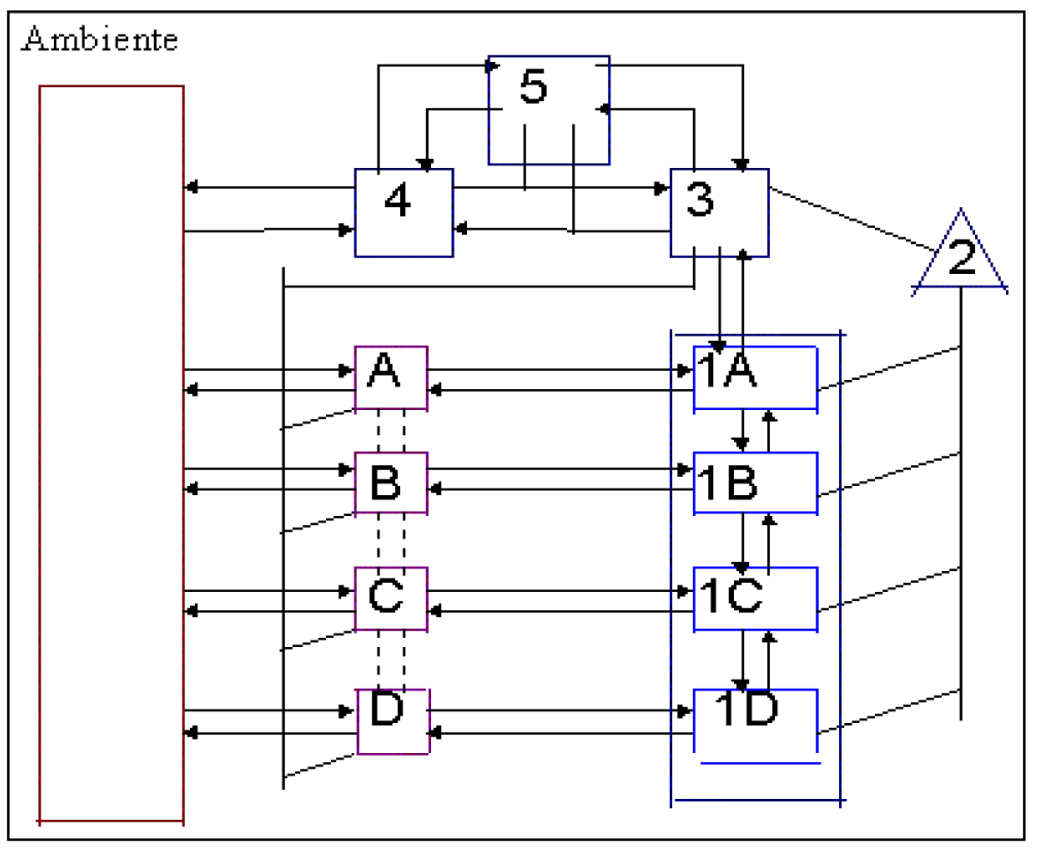

Figure 1: A corporate structure represented by the viable system model of Beer. (Based on Schwaninger, 1993, p. 63, Mattar 2003).

Source: Schwaninger, 1993, p. 63; Mattar, 2003: 02. 
PROBLEMS

OF MANAGEMENT

IN THE $21^{\text {st }}$ CENTURY

Volume 5, 2012

66

The Viable system model of Beer is composed of five subsystems, as well described by Schwaninger (1993): Subsystem 1: ("transaction") identified with the operating system of the Organization, comprises all operational units endowed with autonomy (relative) and can be taken as the object of examination by VSM alone; Subsystem 2: ("coordination") functionally represents an instance that will ensure harmonization between the operation and the objectives of the subsystems subsystem components 1, absorbing the variety (concept of Beer linked to changing conditions, associated with modifications of a complex nature in behavioral conditioning variables of systems) and the uncontrolled oscillations; Subsystem 3: ("control"), such as target activity, function, operations monitoring, responsibility, defining and recognizing the telltale signs of internal performance and, thus, assuming, as shared with assignment 2 Subsystem, the preservation of the Organization's internal stability; Subsystem 4: ("intelligence") combines two main tasks: ensuring the flow of information between systems, particularly between the 5 and the other Subsystem, and capture of the Organization and to the organization information and data relevant to the environment, making them properly;

Subsystem 5: ("the strategy") formulates policies and defines strategies from the understanding and recursive analysis, organization-wide level and in its interaction with the environment, by means of available information, offered primarily by 3 Sub-systems and 4 .

Schwaninger (1993, p. 95) presents the following objectives sought by each one of the three levels of an organization's management:

a) Operational level: the economic efficiency (or particularly profitable);

b) Strategic level: cooperative and competitive capacity of the Organization;

c) Normative level: legitimacy, defined as the potential for meeting the needs and demands of individuals that make up the organization. System means the Union of a set of elements, with a network of functional relations, culminating in the interdependence of its parts, influencing and being influenced by the external environment, in order to achieve a given goal. These systems are typically developed and administered by a team of people with different areas of expertise. This trend has some analogies with the evolution of software development in an analogy used to education.

\section{Educational Learning via Internet}

E-learning through the internet can be defined as a method of teaching and learning that utilizes internet technologies for communication and collaboration on a educational context, understanding the need of students in integrative and that contextualize is part of a complex approach and systemic (DALSGAARD, 2006). This encompasses both the completion of traditional classrooms with internet-based components, as learning environments where the educational process takes place entirely over the internet. The company said CCA consulting, about $90 \%$ of American institutions and higher education are currently using some type of online learning to complement lessons and classroom activities from your travels. Academic and professional organizations agree that the use of internet-based learning environments offer important educational benefits. According to researchers from Cornell University, "the internet enters new functionality in transmitting information to students and provides the possibility of exchanging information through discussion groups."

According to Dwyer et al. (1995), the internet is revolutionizing some areas of study through the expansion of learning opportunities and alternative formats for the transmission of information. One of the advantages in this new educational learning process stands out: a) increased communication student-student and teacher-student; b) feasibility of student-centered teaching techniques; c) availability 24/7 access to course material; d) applying methods of assessment of student progress every step; and administrative work). 
According Kenski (2008), the computer and the internet, and other technological features that were introduced in the practice of teaching in the classroom, education moved and provoked new forms of mediation between the approach of the teacher, the teacher's understanding and knowledge conveyed.

According to Kubala (1998), the internet provides various means to enhance communication between students and teachers, including discussion groups, chats and email. The researchers found that the inclusion of these elements in the courses increases students " motivation and participation in discussion groups and projects. The students "are more likely to participate because of the degree of anonymity that ends up serving as motivation people feel with more capacity. They become more courageous and confronter with regard to the expression of ideas".

\section{The Current Practice in Educational Systems}

Initially it is necessary to devise a system that starts with the identification of the need and setting goals. These objectives must be quantified and measured, covering the areas of effectiveness, cost, schedule and risk. The goals should be analyzed and documented requirements in order to achieve the goals. The requirements are typically determined through market research and, even for the investigation of similar systems already exist, for the benefit of any previous experience in the field facilitate the understanding of the functionality and building a systemic modeling at that if you want to perform. In educational practice, there is a uniform strategy to make education as a system that demands design and maintenance. However, there are some proposed models for reform in education how analogy in some respects similar to the systemic approach. At a school some aspects of learning and project management are made similarly to normal practices included in the systemic theory. Some aspects, however, are made of a very different way.

Educational administrations, to some extent, tend to take responsibility to set the curriculum, but tend not to have direct involvement with what was done in the classroom to cause learning. Quality assurance requires an interactive process of monitoring and correction. In traditional learning systems, such a practice is not providing consistent and reliable monitoring that can remedy the process. Often learning needs are not formally documented or reviewed and there is no validation that make if certain requirements are met. For example, the course materials for teaching standards established. Even when it is shown that the courses or units are not working well, the repair action cannot be taken immediately, this due to issues such as pressures, value to the school, the problems associated with the improvement of quality education without promoting courses that develop. As systemic observation in education can take as input and output the following aspects for higher education:

a) Systemic approach of entry into the optics of the student:

- Student's capacity;

- The enthusiasm of the students;

- Student in the family and socioeconomic context;

- Students' expectations;

- Student with fear of failure;

- Student at his level of stress;

- Teacher-student relationship.

b) Systemic approach of output into the optics of the student:

- The resources made available;

- The way that resources are made available;

- The extent to which students are required to discover things for themselves;

- The level of integration and coordination; 


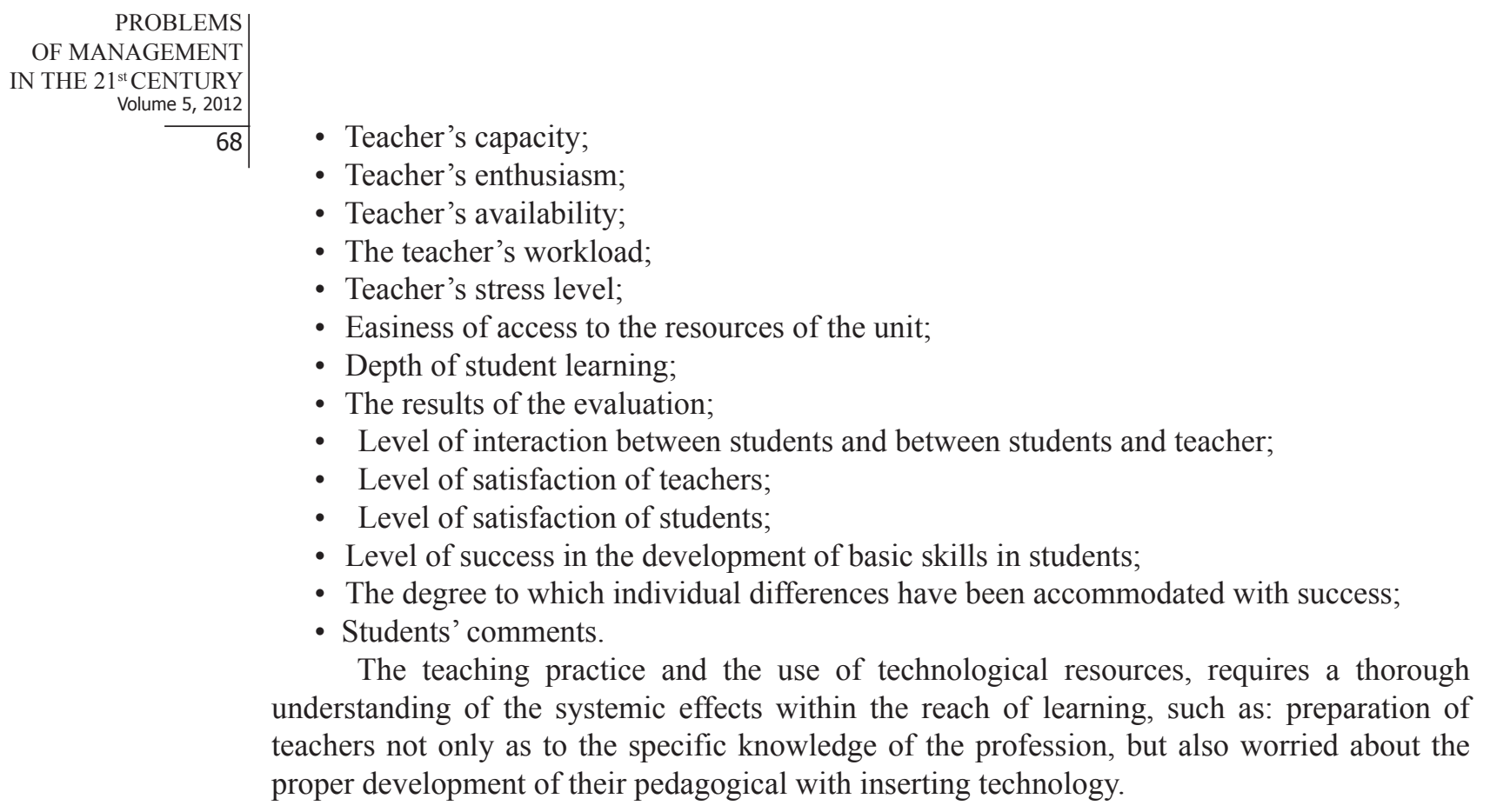

\section{Research Methods}

The methodology for this study was conceived with exploratory empirical analytical approach purpose. Focuses on learning in education from the understanding of systemic vision, with the goal to understand the functionality of learning under systemic levels, extending the managerial treatment. Thus, the method chosen was the qualitative, with an unstructured, exploratory methodology, which offers reflections and understanding the context of the problem.

According to Chauri and Gronhaug (1995), qualitative research is adequate in studies of complex issues, such as human or organizational behavior, allowing the researcher to obtain much more detailed information.

Similarly, Godoy (1995) points out that the qualitative method provides a diverse range of working methods, styles of analysis and presentation of results and various considerations regarding the subject. The quality may be used for cases where you want to explore an issue and your data can be considered conclusive, but cannot be generalized to the target population. With respect to the type of search, it is considered that the investigative content of this research is exploratory type, developed with the goal of providing commercially available approximate overview about specific fact and descriptive and explanatory, that, according to Gil (2007), aims to deepen the knowledge about a particular issue to make it more, trying to describe the characteristics of a phenomenon or predetermined population and its relationship between the variables. It is necessary to consider, according to Cooper and Schindler (2003), which, despite the obvious value of exploratory research, researchers give less attention to exploitation than they should, because there is strong pressure for quick answers.

Thus, this study is exploratory type, grounded in the interest of increasing the knowledge about learning in education. Hair et al. (2005) admit that the exploratory research is useful when the decision-maker has little information. When properly conducted, opens a window into perceptions and behaviors. For Cooper and Schindler (2003), when a researcher, seeking the understanding of the general nature of a problem, the best lookup type is exploratory. In other words, in the present study, there is a rigid structure; the methods are flexible, structured and not qualitative. 


\section{Results}

As seen the systemic approach in the previous sections, there is vulnerability to failure if strategies are not put in place. The success of the phenomenon of distance education, for example, here understood as part of a broader educational innovation is the integration of new information and communication technologies in the educational process. The distance education should not be regulated by market interest or simply the business or political benefit, it is necessary to evaluate the service offered in educational level, and how the institutional investments in facilities have an impact on cost and effectiveness of educational development.

A systemic change can improve results in education. It is important to emphasize, however, that this study steps can be taken to improve the results intended by the institution or organization. The simultaneous consideration of these sets of relationships in the analysis of the teaching-learning process is the basis of a systemic view on education and school. The systemic approach is now widely recognized as part of the new cultural paradigms which seek an integrated vision of the man in its contemporary context what demarcates the complexity. Such complexity admits considerations of internal variables of the individuals, but seen as a result of processes of interaction with the environment. It is known that a system must necessarily be understood as a set of interdependent components (Del Prette and Del Prette, 2001a) that have a dynamic of their own. The adoption of a systemic perspective in the analysis of the teaching-learning process has important implications for research on the factors associated with school performance and also for the educational practice committed to promoting school success and the minimization of the scholastic failure. A systemic approach of the educational process by centralizing the student teacher relationships cannot disregard the study of individual characteristics of teachers and students, and another, the influence of the elements that characterize the school context; or minimizes the importance of the political, economic and cultural aspects of education. On the contrary, should consider the weight of micro and macro systems on the characteristics of interpersonal and intergroup relationships, that is, to understand the environment in its educational context for the promotion of knowledge.

\section{Conclusions}

This study makes it possible to understand that the educational process has its origin in this or that element of an educational situation, but in the very phenomenon of educational relationship with the environment in which the institution is located. This interrelation motion system defines a particular transactional field which in turn can be divided into subfields interdependent as, for example, biology and genetics, with its intermediate factors (intelligence, maturity, etc.) the communication style, the didactic/pedagogical model, the contents, etc. This view rejects the traditional rethinking in transmission of knowledge, as is the case of classrooms in virtual environments, through distance learning. It has been argued that modern education systems can benefit from the application of the concepts of systemic management, and a conceptual revision has been given as a suggestion on the basics to start applying in education. In short, the systemic approach in educational learning process has been marked by the same principles that give support to this view in the contemporary business-scenario complexity. The pedagogical concept underlying this perception tends to assume the logic of education in an alternative process of transmitting knowledge integrating teaching methods in a virtual environment as a means of social inclusion and of breaking paradigms, where systemic adverse effects take approaches in understanding the processes of entry and exit which leads to education as a product and not a commodity. In this direction, it is understood that this approach is accepted by the systemic theory should fill the fragmentation and the oppositions from learning and education proposals that currently recommends a model via virtual environment that demonstrates how the new paradigm in educational learning. 


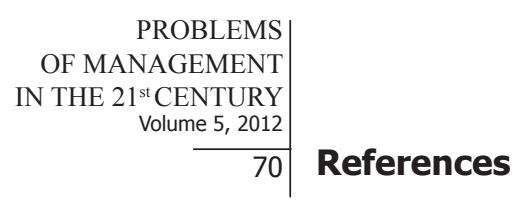

Beer, S. (1969). Cibernética e Administração Industrial. Rio de Janeiro: Zahar.

Bio, S. R. (1985). Sistema de informação: um enfoque gerencial. São Paulo: Atlas.

Chiavenato, I. (2003). Introdução a Teoria Geral da Administração: uma visão abrangente da moderna administração das organizações. 7. ed. Elsevier.

Cooper, D. R., Schindler, O. S. (2003). Métodos de pesquisa em administração. 7. Ed. Bookman.

Dalsgaard, C. (2006). Social software: e-Learning beyond learning management systems. EURODL.

Del Prette, Z. A. P., Del Prette, A. (2000). Treinamento em habilidades sociais: panorama geral da área. In: Haase, V. G., Rothe-Neves, R. C., Teodoro, M. L. M., Wood, G. M. O., (Eds.), Psicologia do desenvolvimento: contribuições interdisciplinares (pp. 74-75). Belo Horizonte: Health.

Dwyer, D., Barbieri, K., Doerr, H. (1995). Creating a Virtual Classroom for Interactive Education on the Web. The Third International World Wide Web Conference.

Feenburg, A. (2001). Democratizing Technology: interests, codes, rights. The Journal of Ethics, 5, 177195.

Friesen,N. (2008 ). CriticalTheory:acritiqueofideologyandthemythsofe-learning . Ubiquity 9. Available from: http://ubiquity.acm.org/article.cfm?id=1386860 (last accessed July 3, 2012).

Ghauri, P. N., Gronhaug, K. (1995). Research methods in business studies: practical guide. New York: Prentice Hall.

Gil, A. C. (2007). Como elaborar projetos de pesquisa. 4. Ed. São Paulo: Atlas.

Godoy, A. S. (1995). Introdução à pesquisa qualitativa e suas possibilidades. Revista de Administração de Empresas - RAE, 35, 57-63.

Hair, J., et al. (2005). Fundamentos de Métodos de Pesquisa em Administração. Porto Alegre: Bookman.

Kenski, V. M. (2008). Educação e tecnologias o novo ritmo da informação. $4^{\mathrm{a}}$ Ed. Campinas, SP:

Papirus.

Kubala, T. (1998). Addressing student needs: Teaching on the internet. T.H.E. Journal, 25 (8), 71-74.

Mattar, F. N. (2003). Sistema de Informações Gerenciais de mercado: entendimento da visão, relação $e$ compreensão pelos diferentes níveis administrativos de uma organização. São Paulo: Atlas.

Oliver, M. (2005). The problem with affordance. The E-Learning Journal, 2, 402-413 .

Petit, T. A. A. (1967). A Behavioral Theory of Management. Academy of Management Journal, Dec.

Schwaninger, M. (1993). A concept of organizational fitness. In: Espejo, R and Schwaninger, M (Eds.), Organisational Fitness: corporate effectiveness through management cybernetics. Campus Verlag.

Selwyn, N. (2010). The use of computer technology in university teaching and learning: a critical perspective. Journal of Computer Assisted Learning, 23 (2), 83 - 94.

Advised by Dana Egerova, University of West Bohemia, Czech Republic

Received: September 30, 2012

Accepted: October 17, 2012 
Nilton Cesar LIMA, Antonio Sergio Torres PENEDO, Marcio Mattos Borges de OLIVEIRA, Sonia Valle Walter Borges de OLIVEIRA, Jamerson Viegas QUEIROZ. Application of Systemic Vision in the Educational Process

PROBLEMS

OF MANAGEMENT

IN THE $21^{\text {st }}$ CENTURY

Volume 5, 2012

71

\begin{tabular}{|c|c|}
\hline Nilton Cesar Lima & $\begin{array}{l}\text { PhD., Adjunct Professor, Federal University of Alagoas, Campus } \\
\text { Universitário, s/n, Tabuleiro dos Martins, Caixa, 1564, Maceió, } \\
\text { Brazil. } \\
\text { Phone: +55 } 8230322405 . \\
\text { E-mail: cesarlim@yahoo.com }\end{array}$ \\
\hline Antonio Sergio Torres Penedo & $\begin{array}{l}\text { PhD., Adjunct Professor, Federal University of Rio Grande do } \\
\text { Norte, Campus Universitário, s/n - Lagoa Nova Caixa, 1524, } \\
\text { Natal- RN, Brazil. } \\
\text { E-mail: astpenedo@yahoo.com.br }\end{array}$ \\
\hline Marcio Mattos Borges de Oliveira & $\begin{array}{l}\text { PhD., Associate Professor, University of Sao Paulo, Campus } \\
\text { Universitário, s/n } \square \text { Monte Alegre, Caixa, 2025, Ribeirão Preto- } \\
\text { SP, Brazil. } \\
\text { E-mail: mmattos@usp.br }\end{array}$ \\
\hline Sonia Valle Walter Borges de Oliveira & $\begin{array}{l}\text { PhD., Associate Professor, University of Sao Paulo, Campus } \\
\text { Universitário, s/n } \square \text { Monte Alegre, Caixa, 2025, Ribeirão Preto- } \\
\text { SP, Brazil. } \\
\text { E-mail: soniawv@usp.br }\end{array}$ \\
\hline Jamerson Viegas Queiroz & $\begin{array}{l}\text { PhD., Adjunct Professor, Federal University of Rio Grande do } \\
\text { Norte, Campus Universitário, s/n - Lagoa Nova Caixa, 1524, Na- } \\
\text { tal-RN, Brazil. } \\
\text { E-mail: viegasqueiroz@gmail.com }\end{array}$ \\
\hline
\end{tabular}

